\title{
PERBAIKAN PRODUKTIVITAS LEBAH MADU LOKAL (APIS SP) BAGI MASYARAKAT PINGGIRAN HUTAN KECAMATAN PUPUAN KABUPATEN TABANAN
}

\author{
N.W. Siti ${ }^{1}$, N.N. Candraasih K. ${ }^{2}$, dan N.W. Suniti ${ }^{3}$
}

\begin{abstract}
ABSTRAK
Pengabdian yang bertujuan untuk meningkatkan pengetahuan dan keterampilan peternak tentang teknik budidaya beternak lebah, telah dilaksanakan pada kelompok ternak lebah Batukaru desa Sanda Pupuan Tabanan pada hari Sabtu 29 Juli 2017. Metode yang digunakan adalah penyuluhan, demonstrasi dan pendampingan tentang teknik budidaya ternak lebah, cara membuat stuf dari kayu bekas dan cara panen madu yang benar. Hasil dari pengabdian adalah : (1) Kehadiran peternak $100 \%$; (2) pengetahuan dan keterampilan peternak teknik budidaya lebah madumeningkat dari $20 \%$ menjadi $90 \%$; (3) kelompok lebah Batukaru sudah mampu membuat stuf dari kayu bekas, (4) terwujud denplot lebah madu 20 stuf dari kayu bekas; (4) Terbentuk struktur organisasi kelompok lebah madu Batukaru, (5) kelompok lebah Batukaru sudah mampu menindahkan ratu dari stuf yang satu ke stuf yang lain, (6) Kelompok lebah Batukaru mengetahu hasil lebah terdiri dari madu, follen, royal jelly serta lilin dan (7) hasil analisis proksimat dari medu adalah Kadar air 38,34\%, kadar abu $0,50 \%$ dan protein $1,36 \%$ (\% berat basah). Dari hasil pengabdian dapat disimpulkan bahwa kelompok ternak lebah Batukaru desa Sanda Tabanan sudah bisa membuat stuf dari kayu bekas dan sudah terwujud denplot lebah sebanyak 20 stuf dari kayu bekas.
\end{abstract}

Kata Kunci : peternak, penyuluhan, ternak lebah, desa Sanda Pupuan Tabanan

\begin{abstract}
Community service aimed at improving the knowledge and skills of breeders about the cultivation techniques of raising bees, have been implemented in the Group livestock bees Batukaru in Tabanan Pupuan Sanda village on Saturday 29 July 2017. The method used is the extension, demonstration and accompaniment of bees, livestock farming techniques in how to make a wooden former stuf and how to harvest honey. The result of the dedication were: (1) the presence of breeders $100 \%$; (2) the knowledge and skills of the engineering increase bee breeders from $20 \%$ to $90 \%$; (3) a group of bees Batukaru is already capable of making stuf of wood used, (4) realized denplot honey bee 20 stuf from secondhand wood; (4) the structure of the Organization Formed groups of honeybees Batukaru, (5) groups of bees Batukaru already capable Queen of stuf to the other stuf, (6) groups of bees Batukaru knows the result of bees consists of honey, royal jelly and Polen, candles and (7) the results of the analysis of the prokximate bees is $38.34 \%$ water content, rate of $0.50 \%$ ash and protein $1.36 \%$ (\% wet weight). From the results it can be concluded that the Group devotion livestock bees Batukaru village Tabanan Sanda can already make a stuf from wood used and already realized denplot bees as much as 20 stuf of wood used.
\end{abstract}

Keywords : extension, livestock breeders, the bees, the village of Sanda Pupuan Tabana

\footnotetext{
${ }^{1}$ Staf Pengajar Fakultas Peternakan Universitas Udayana, wayansiti@unud.ac.id

2,3 Staf Pengajar Fakultas Pertanian Universitas Udayana
} 


\section{PENDAHULUAN}

Kelompok tani lebah madu lokal (Apis Cerana) di di desa Sanda Pupuan Tabanan, Bali berlokasi $25 \mathrm{~km}$ dari pusat kota Tabanan. Kelompok tani lebah madu lokal tersebut rata-rata beranggotakan 15 orang dan mengembangkan budiaya lebah madu lokal sejak tahun 2000. Mereka bersemangat mengembangkan lebah madu lokal krena lokasinya berada di daerah hutan yang ditanami kopi dengan potensi sumber daya alam untuk lebah madu berupa ketersediaan bunga vegetasi hutan dan bunga kopi yang melimpah pada waktu musim berbunga. Pilihan mereka pada lebah madu lokal karena rasa madunya lebih manis dan khas serta harganya sangat tinggi (Rp. 200.00-Rp. 300.000 per liter).

Madu adalah suatu bahan makanan yang dihasilkan oleh lebah yang merupakan satu - satunya pemanis yang bisa digunakan manusia tanpa pengolahan terlebih dahulu. Madu mengandung berbagai jenis komponen yang sangat bermanfaat bagi kesehatan manusia. Komponen -komponen itu adalah karbohidrat, asam amino, mineral, enzim, vitamin dan air. Selain dikonsumsi secara langsung, madu juga dimanfaatkan untuk industri makanan, industri minuman, industri farmasi, industri jamu, dan industri kosmetik (Apriani D. et al., 2013)

Berdasarkan keasliannya madu terbagi dalam dua jenis yaitu madu alami dan madu buatan. Madu alami adalah madu yang diambil dari hutan yang beraneka jenis tanaman tempat bergantungnya lebah madu, sedangkan madu buatan adalah madu yang dibuat dengan menggunakan gula sebagai pengganti nectar dan bahan lainnya seperti soda kue, tepung kanji Esens madu, glukosa, dan air minum. Madu alami diambil dari hutan yang memiliki beraneka jenis tanaman tempat bergantungnya lebah madu. Madu tidak mengandung bahan kimia yang berbahaya, hampir seluruh zat dalam madu dapat terserap oleh tubuh dan hanya kurang dari 1/200 bagian madu yang akan dibuang oleh tubuh. Dari segi kualitas, madu asli sangat populer dimata masyarakat. Madu asli ini sangat digemari karena diyakini memiliki khasiat yang lebih dibanding dengan madu yang dijual dipasaran (Apriani D. et al., 2013).

Menurut Standar Nasional Indonesia (SNI) 01-3545-1994, madu adalah cairan manis yang dihasilkan oleh lebah madu berasal dari berbagai sumber nectar. Nektar adalah semacam cairan yang dihasilkan oleh kelenjar nectar tumbuhan, kaya akan pelbagai bentuk karbohidrat (3-87\%), seperti sukrosa, fruktosa dan glukosa, mengandung sedikit senyawa-senyawa pengandung nitrogen, seperti asam-asam amino, amida-amida, asam-asam organik, vitamin-vitamin, senyawa aromatik dan juga mineral-mineral. Madu yang telah dimasak mengandung fruktosa $41.0 \%$, glukosa $35.0 \%$, sukrosa $1.9 \%$, dekstrin $1.5 \%$, mineral $0.2 \%$, air $17 \%$ dan zat-zat lain diantaranya asam amino sebanyak $3.5 \%$.

Rasa manis madu alami memang melebihi rasa manisnya gula karena rasa manis madu alami mempunyai tingkat kemanisan satu setengah kali rasa manis gula pasir. Rasa manis madu alami tidak memiliki efek-efek buruk seperti halya gula pasir, karena pada madu alami tingkat kemanisanya dipengaruhi oleh karbohidrat sederhana yang berupa monosakarida 79,8\% dan air 17\% sehingga mudah diserap oleh tubuh (Prasetyo, Minarti dan Cholis, 2014).

Permasalahan yang dihadapi oleh kelompok ternak lebah Batukaru desa Sanda Pupuan Tabanan adalah frekwensi panen madu lokal yang relatif lama, yakni 2-6 bulan. Jika frekwensi panen ditingkatkan, maka bisa panen tiap 2-3 bulan, kualitas madu yang belum maksimal yang meliputi rasa, aroma dan warna madunya, sehingga harganya berkisar Rp. 100.000 per liter, jika kualitas madunya sangat baik, maka harganya bisa mencapai RP. 300.000 per liter dan Kuantitas produksi madu lokal yang belum optimal, yakni tiap kotak lebah hanya 0,5 liter madu. Jika produksi madu lokal tersebut bisa ditingkatkan, maka tiap kotak lebah mampu menghasilkan 1-1,5 liter madu.

\section{9 | BULETIN UDAYANA MENGABDI}




\section{METODE PELAKSANAAN}

Metode pelaksanaan yang dilakukan adalah ceramah, demontrasi dan denplot ternak lebah pada kelompok Ternajk Batukaru. Materi ceramah meliputi : (1) teknik budidaya beternak lebah ; (2) pembuatan stuf dari kayu bekas, dan (3) pelatihan pengemasan produk madu dan studi banding ke kelompok lebah Sari Bunga di Melaya Jembrana. Lebah madu dianalisis proksimat untuk mencari bahan kering, bahan organik dan protein kasar menggunakan metode A.O.A.C., 1990.

\section{HASIL DAN PEMBAHASAN}

Kegiatan pengabdian kepada masyarakat yang bertema Perbaikan produktivitas lebah madu lokal (Apis sp) bagi masyarakat pinggiran hutan Kecamatan Pupuan Kabupaten Tabanan telah dilaksanakan hari Sabtu 29 Juli 2017 di Wantilan desa Sanda. Kegiatan yang dilakukan meliputi: (1) penyuluhan dan demontrasi tentang : (1) teknik budidaya beternak lebah; (2) cara membuat stuf dari kayu bekas dan ukuran dengan ukuran yang benar dan (3) menentukan lokasi jarak penempatan stuf pada pohon diberikan oleh Ir. Sunarta dosen Fakultas Pertanian Unud. Denpasar dan (4) pelatihan pengemasan produk diberikan oleh disperidag Kabupaten Tabanan Penyuluhan. Pada hari Sabtu 5 Agustus 2017 kelompok ternak lebah Batukaru diajak studi banding ke kelompok ternak lebah Sari bunga yang sudah maju berlokasi di desa Melaya Kabupaten Jembrana. Pada saat penyuluhan berlangsung, dilakukan pretest menanyakan apakah pernah membuat stuf dari kayu bekas dan perlengkapan didalamya. Hasil pretes $20 \%$ (3 orang dari 15 orang) yang pernah mendengar teknik pembuatan stuf dari kayu bekas, cara menindahkan ratu dari 1 stuf ke stuf yang lain dan cara panen madu yang benar, namun hasil postes meningkat menjadi 90\% (Tabel 3.1), ini artinya team penyuluh sudah berhasil memberikan materi kepada kelompok ternak. Terwujudnya denplot lebah madu dengan stuf dari kayu bekas sebanyak 20 buah, sebagai modal awal untuk menghasilkan madu. Hasil analisa laboratorium menunjukkan bahwa kadar air madu kelompok ternak lebah Batukari desa Sanda adalah 38,34\%, kadar abu 0,50\% dan kadar protein 1,36\%. Kandungan nutrient dari lebah madu berbeda-beda sesuai dengan nectar (jenis tanaman sebagai makanan lebah) dan temperature tempat stufnya.

Respon khlayak sasaran yakni kelompok ternak lebah Batukaru desa Sanda cukup baik, terbukti dari kehadiran pada saat penyuluhan $100 \%$, tingkat pengetahuan dan keterampilan meningkat dari $20 \%$ menjadi $90 \%$ serta saat studi banding ke Jembrana semua kelompok ikut praktik membuat stuf serta memindahkan ratu dari 1 stuf ke stuf yang lainnya. Dari penjajagan awal nampaknya tanggapan aparat khususnya aparat di kantor Prebekel desa Sanda, Tabanan cukup baik terbukti pada saat sosialisasi team dari Unud diterima dengan terbuka dan membuat jadwal untuk melaksanakan penyuluhan demonstrasi dan pendampingan pada kelompok ternak lebah Batukaru. Pada saat penyuluhan berlangsung Prebekel desa Sanda ikut membuka dan mendampingi sampai kegiatan selesai. Demikian juga pada saat studi banding ke Jembrana, Prebekel ikut dan sebagai pemandu pada saat di lapangan. Hasil analisis proksimat madu dilihat pada tabel 3.2, Pelaksanaan kegiatan dikelompok ternak lebah Batukaru dapat dilihat pada gambar 3.1, 3.2, 3.3 dan 3.4.

\section{KESIMPULAN DAN SARAN}

Kesimpulan yang bisa diambil dari kegiatan pengabdian masyarakat adalah: (1) Tingkat pengetahuan peternak tentang teknik budidaya beternak lebah meningkat dari $20 \%$ menjadi $90 \%$; (2) kelompok ternak lebah Batukaru $80 \%$ sudah bisa membuat stuf dari kayu bekas dan mengeti teknik memindahkan ratu dari 1 stuf ke stuf yang lain (3) kandungan nurien madu berbeda tergantung dari nectar temperatr tempat stuf.

VOLUME 17 NOMOR 02, APRIL 2018 | 30 
Saran yang dapat diajukan adalah perlu dilakukan pendampingan secara berkelanjutan agar inovasi yang diberikan dapat diterapkan secara tepat guna sehingga peternak lebah mampu menghasilkan madu yang optimal dengan kualitas yang baik.

Pelaksanaan kegiatan pengabdian ini dapat dilihat pada Gambar1-4.

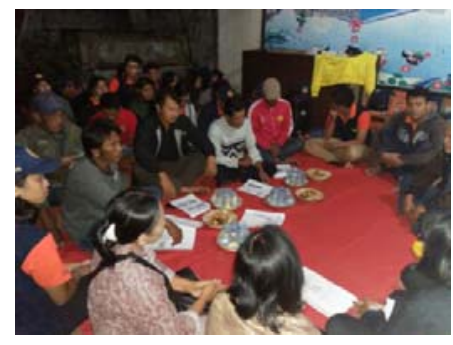

Gambar 1. Penyuluhan Budidaya beternak lebah lokal

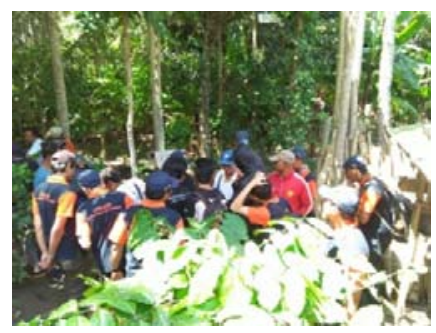

Gambar 3. Teknik memindah ratu ke stuf yang masih kosong

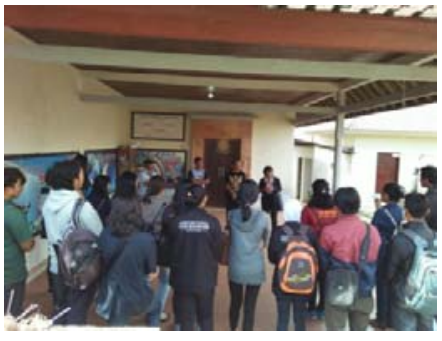

Gambar 2. Sosialisasi DPL dan Mhs KKN di Kantor desa Sanda

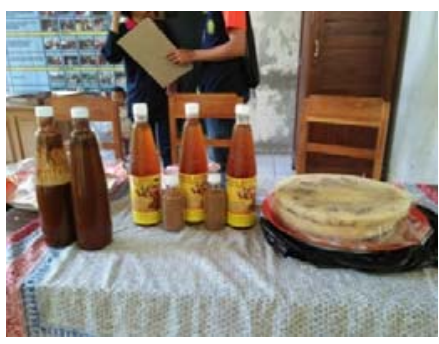

Gambar 4. Produk dari lebah : madu, polen padat, polen cair dan lilin

Tabel 3.1. Partisipasi Kelompok Ternak Batukaru Dalam Kegiatan Penyuluhan dan Demonstrasi

\begin{tabular}{|l|l|l|l|}
\hline No & \multicolumn{1}{|c|}{ Kegiatan } & Kelompok ternak & \multicolumn{1}{c|}{$\%$} \\
\hline 1 & Penyuluhan & & \\
\hline & a. Kehadiran & 20 & 100 \\
\hline & b. Bertanya/mengungkapkan masalah & 15 & 75 \\
\hline c. Pretes & 4 & 20 \\
\hline d. Postes & 20 & 100 \\
\hline e. Pada saat Demonstrasi & 20 & 100 \\
\hline
\end{tabular}

Tabel 3.2. Kandungan Madu, Polen Padat dan Polen Cair

\begin{tabular}{|c|c|c|c|c|}
\hline Perlakuan & \multicolumn{4}{|c|}{ Kandungan nutrien jerami padi } \\
\hline & Kadar air (\%) & Kadar abu (\%) & $\begin{array}{c}\text { Protein Kasar } \\
(\mathbf{\%})\end{array}$ & Standar SNI \\
\hline Madu & 38,34 & 0,50 & 1,36 & - \\
\hline Polen padat & 14,0 & 3,27 & 24,82 & - \\
\hline Polen cair & 68,74 & 1,43 & 7,88 & - \\
\hline
\end{tabular}

Keterangan : * Hasil analisa Laboratorium Teknologi Hasil Pertanian Unud (2017) 


\section{UCAPAN TERIMA KASIH}

Penulis mengucapkan terima kasih kepada KEMENRISTEK DIKTI atas dana yang diberikan lewat program Ipteks bagi Wilayah (IbW), Rektor Universitas Udayana, Ketua LPPM beserta staf terima kasih atas seleksi proposal dan tenaga yang diberikan dalam pelaksanaan di lapangan, sehingga pengabdian kepada masyarakat terlaksana sesuai rencana.

\section{DAFTAR PUSTAKA}

Badan Statistik Propinsi bali. 2012. Bali dalam Angka.

Anon, 2011. Monografi Desa Sanda.

Kuntadi. 2010. Pengembangan Budidaya Lebah Madu Dan Permasalahannya. Pusat Penelitian dan Pengembangan Konsevasi dan Rehabilitasi Badan penelitian dan Pengembangan kehutanan 